\title{
WATERSHED MANAGEMENT WITH SPECIAL EMPHASIS ON FRESH WATER WETLAND: A CASE STUDY OF A FLOOD PLAIN WETLAND IN WEST BENGAL, INDIA
}

\author{
M. BISWASROY ${ }^{1, *}$ \\ N.R. SAMAL ${ }^{2}$ \\ P.K. ROY ${ }^{3}$ \\ A. MAZUMDAR ${ }^{3}$
}

\author{
${ }^{1}$ Department of Geography, \\ G. C. B.T.College, Habra, West Bengal, India \\ ${ }^{2}$ Dept. of Civil Engineering, National Institute of Technology, \\ Durgapur- 713209, West Bengal, India \\ ${ }^{3}$ School of Water Resources Engineering, Jadavpur University \\ Kolkata-700 032, West Bengal, India
}

Received: 04/11/09

Accepted: 24/02/10 *to whom all correspondence should be addressed: e-mail: malabikabiswasroy@gmail.com

\begin{abstract}
The last few decades we have witnessed an enormous rise in awareness of the importance of wetlands. Mathura bee ${ }^{1}$ has been assumed to take the attention in recent years because of its ecological significance in terms of flood control, water purification, aquatic productivity, and microclimatic regulation etc. The aim of this paper is to present a complete scenario of Mathura beel through different analyses. To materialize the main objective, the water quality monitoring, socioeconomic analyses, and a perception study on wetland use and wetland threat are considered separately. In this study, the objective was extended to observe the complete socio-economic status, and a detailed perceptional study on wetland use, and wetland threat. At the end of the study, detailed management options have been given to protect and to conserve the economy and the ecosystem of Mathura beel.
\end{abstract}

KEYWORDS: Mathura beel, water quality monitoring, socio-economic analysis, perception study, watershed management.

\section{INTRODUCTION}

Wetlands are also believed to play a significant role in global climatic change by acting as a source of atmospheric green-house gases such as methane, carbon, nitrogen (Jansson et al., 1994). Global biodiversity is also enhanced by wetlands, as they are vital for the survival of disproportionately large number of threatened and endangered species (Mitsh and Gossolink, 1993). Wetlands cover approximately $6 \%$ of the Earth's surface and provide to the human population with a host of goods and services including food storage, water quality sustenance, agriculture production, fisheries and recreation (Acreman and Holis, 1996). However, around the world wetland are being lost and degraded, as economic development resulted in increasing pressure to drain and reclaim land for agriculture, industrial and others uses. In such situation, a complete study on wetlands is necessary to increase the awareness for protecting and preserving the wetland.

Kusler et al. (1999) stated the definition of watershed management. According to his study, traditional water and watershed management is an approach that integrates ecosystem management with traditional water and watershed management goals and techniques. It manages water resources, wetlands and related ecosystems. The watershed management in a flood plain wetland is very important because it has several benefits to the whole community. These benefits include (a) improved achievement of traditional watershed management goals, (b) improved

\footnotetext{
${ }^{1}$ Beel: Beel (or Bheel) is a natural lake, generally an oxbow in Assam and West Bengal (Mukherjee, 2008; Gopal and Sah, 1995). Beel is a term for a pond (wetland) with static water (as opposed to moving water in rivers and canals.
} 
protection and restoration of wetlands and related ecosystems, (c) improved ability to allocate lands throughout a community to their most appropriate uses and protect the overall "quality of life" through greenways, recreation areas, and open spaces, and (d) improved ability to meet landowner needs through increased coordination and reduced duplication and costs in regulations (Kusler et al., 1999).

Several studies are available on multiple purposes wetland management. For examples, Donah (1995) emphasized about wetland conservation taking the effect of weather pattern suitable for agricultural production. Tiega (2002) stated that, to conserve wetland biodiversity, wetland inventory and assessment, water and wetland policies/strategies, legislation and regulation, pollution control, economic valuation techniques, training and environmental education, and public awareness are compulsory and being made in Africa (Thompson, 1996). IUCN, CNRS-Bangladesh (2006) provided information on the values of conserving Hakaluki haor in terms of its economic, ecological and social benefits for local communities and for the nation at large. However, Kangalawe and Liwenga (2005) focused on the opportunities and challenges related to integrated water resources management in Kilombero valley, Tanzania. Moreover, Mwakubo et al. (2004) examined the influence of natural shocks, local institutions and livelihood assets in the management of wetlands in the Lake Victoria watershed basin. It has also been observed in this study, the incidences of floods, drought, epidemic diseases, and social structure in Uganda, Kenya and Tanzania through a comparative approach. Turner (2000), even so, emphasized on an integrated wetland research framework, which suggests that a combination of economic valuation, integrated modeling, stakeholder analysis, and multicriteria evolution can provide complementary insights into sustainable and welfare-optimizing wetland management and policy. Whereas, Singh et al. (2001) approached the estimating costs and benefits of resources and water quality degradation in Lake Nainital. In fact, Biswas et al. (2007) examined the water quality of two wetlands in details and showed a comparative study of a number of distinct parameters, which are perceived by the inhabitants of these wetlands. Side by side, Biswas et al. (2005) delineated a case study of Bhomra beel, India by analyzing the water quality and assessing people's perception vis-à-vis the utilities and associated threats. Furthermore, Makombe and Sampath (2003) evaluated the influence of socioeconomic variables on participating in marketing cooperatives on the financial performance of small holder irrigation systems in Zimbabwe. Dixon (2008), whereas, examined the cases of local community based institutions involved in wetland management in western Ethiopia. Boyacioglu et al. (2005), however, applied multivariate data analysis to the large water quality data sets of the Buyuk Menderes River Basin in analyzing the surface water contamination and determining the correlations between water quality parameters. Zeng and Rasmussen (2005) aimed to present a strategy that reduces the measured parameters, locations, and frequency without compromising the quality of the monitoring program. Bakker and Matsuno (2001), whereas, presented the environmental impact of irrigation and a framework for valuing water for its multiple and often competing uses, especially focusing on water uses for ecological services.

Biswas (2008) stated that when the river basin has reduced its depth due to siltation and during the monsoon, the excessive water is spread and distributed in both sides of the river while the silt is deposited on low-lying land nearby riverbanks. As a result, a flood plain is developed on that area. In India, the flood plain is generally found in the Ganga-Meghna-Brahmaputra (GBM) basin. The Bhagirathi-Hooghly river system has created the flood plain of West Bengal (Biswas 2008). The Mathura beel is a flood plain wetland in which a detailed study on Mathura beel is required on the GBM basin to understand the different ecosystem services available. Mathura beel is a fresh water lake, enriched with high biodiversity level and variable ecological cycle.

\section{THE STUDY AREA: THE PHYSICAL ENVIRONMENT}

The Mathura beel, area of which 184 ha, is categorized under two districts namely Nadia district and North $24^{\text {th }}$ Parganas district of West Bengal, India. The Mathura Beel is located in between $22^{\circ} 25^{\prime} \mathrm{N}$ $-23^{\circ} 55^{\prime} \mathrm{N}$ and $88^{\circ} 30^{\prime} \mathrm{E}-88^{\circ} 50^{\prime} \mathrm{E}$. The elevation of the area is about 9 to 10 meters above mean sea level. The general slope of the area ranges from $0-10 \%$. The Mathura bel has a substantial rainfall of $1555.16 \mathrm{~mm}$ per annum on an average; but the monthly distribution is much uneven. Besides, the temperature regime is significant, the daily maximum ranging from $10.15^{\circ} \mathrm{C}$ to over $28^{\circ} \mathrm{C}$. Due to excessive heat, the loss of moisture through evaporation is considerable over the Mathura beel. In fact, at some places, the total monthly evaporation during the pre-monsoon, post monsoon $(393.61 \mathrm{~mm}$ ) far exceeds the total monthly rainfall of $235.48 \mathrm{~mm}$. However, during the five 
wet months (June to October) the evaporation loss is less than the rainfall, resulting in a surplus water balance. During the five wet months, the water surplus totals to $590.13 \mathrm{~mm}$ which constitutes $37.95 \%$ the total annual rainfall and is available as runoff down the Mathura beel. The total replenishable groundwater is estimated as $23.09 \mathrm{BCM}$ in West Bengal. The length and the width of the beel is $9 \mathrm{~km}$ and $0.5 \mathrm{~km}$ respectively. The status of this wetland is cut off meander or offshore of River Ganga. The average depth during rainy season and dry period (March to mid-June) is between 1 and $1.5 \mathrm{~m}$ and between 0.2 and $0.5 \mathrm{~m}$. The main fishing activities of Mathura beel have been distributed among the Fishermen Co-operative Society, which was constituted in 1950 at Kapachakla Gram-Panchayet ${ }^{2}$, presently has 509 members. The study area is penciled in the following Figure 1.

Like the other wetlands in rural India, Mathura beel, also, provides lists of goods and services to the stakeholders, who live around this wetland. In this backdrop an attempt is made to portray a perception study on wetland uses and wetland threats and also, to explore the socio-economic status of stakeholders of Mathura beel utterly. In the present investigation, the complete scenario of sustainability of Mathura beel is aessesed through variable qualitative and quantitative analysis.

\section{WATER QUALITY MONITORING AND METHODS}

Water samples were collected from different locations of the Mathura beel for the determination of physio-chemical and bacteriological quality of wetland water. Certain relevant parameters (Table 1) have been analyzed to assess the water quality of Mathura beel and to identify the eco-services that could be provided. Further, the potential improvements or interventions needed to maintain the standards specified at the national level, are discussed. Three water sampling stations were selected in the lake. The annual average BOD (Biochemical Oxygen Demand) (5 day, $20^{\circ} \mathrm{C}$ ) of the lake water has been found to be $2.58 \mathrm{mg} \mathrm{L}^{-1}$ (ranging from $2.25 \mathrm{mg} \mathrm{L}^{-1}$ to $3.1 \mathrm{mg} \mathrm{L}^{-1}$ ). As sewage is not being discharged in the wetland (this has been verified during site survey), the contribution of organic load in the lake could be from residue of aquatic plants and solid wastes. The average $\mathrm{pH}$ values of the lake water are found to vary from 7.0 to 7.5 . The $\mathrm{pH}$ of the lake water is remaining slightly in alkaline range, which also substantiates the growth of algae in the wetland. The algal growth is not very high (which indicates less chlorophyll-a data as depicted in Table 1) as the BOD of the lake water ranged between 2.25 to $3.1 \mathrm{mg} \mathrm{L}^{-1}$. The algae in the lake are growing due to photosynthesis to maintain symbiotic relation with bacteria. The average DO (Dissolved Oxygen) level in the lake ranged between 4.9 to $5.80 \mathrm{mg} \mathrm{L}^{-1}$ at average temperature of $19.820 \mathrm{C}$. Hence oxygen saturation level of $56 \%$ to $78 \%$ is maintained in the wetland. A favorable bio-environment for fish is maintained in the wetland at present. The average sulphate concentration in the wetland remains to be $37.95 \mathrm{mg} \mathrm{L}^{-1}$ (Table 1 ).

This indicates that the agricultural washout during surface runoff is high. The lake water maintains a typical property of surface water body. The phosphorous content in the lake water has been estimated to be $0.1256 \mathrm{mg} \mathrm{L}^{-1}$ (Table 1). The bacteriological analysis was conducted in the laboratory to access total coliform and faecal coliform. The Total Coliform (TC) was varied between 350 and 1000 per $100 \mathrm{ml}$. In the above locations, the Faecal Coliform (FC) was varied between 9 to 12 MPN per $100 \mathrm{ml}$. The variation in coliform counts suggests localized contamination of the water of the Mathura beel. The average TC and FC accordingly has been found to be 750 MPN per $100 \mathrm{ml}$ and 10 MPN per $100 \mathrm{ml}$ respectively as depicted in Table 1. Central Pollution Control Board has classified surface water as per water quality criteria and designated best use. Using the same standard the Mathura beel can be classified as class ' $\mathrm{C}$ '.

\footnotetext{
${ }^{2}$ Gram-Panchayet: Gram-Panchayet is an elected body formed by some elected members from different villages. It is self-local administrative body
} 


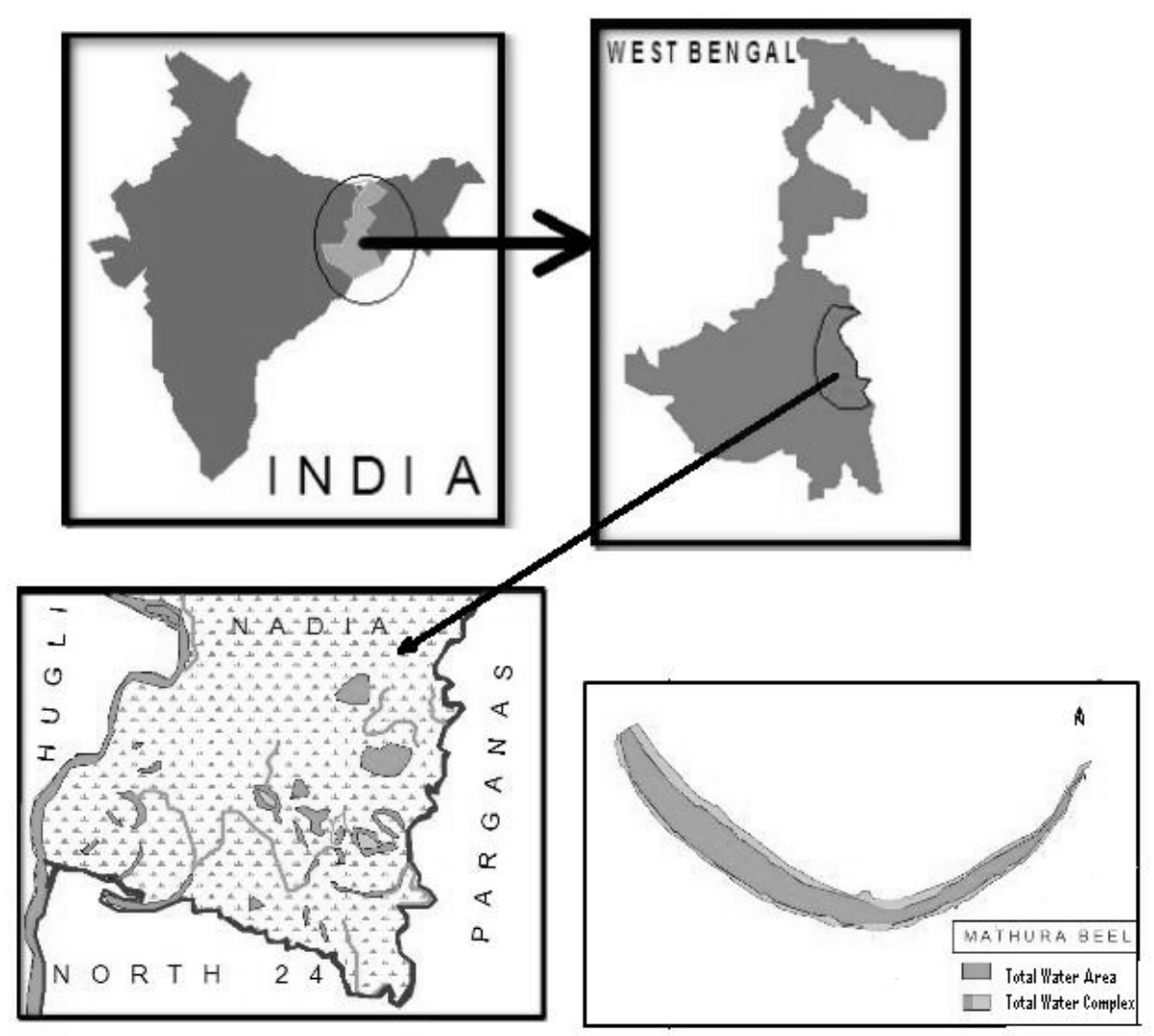

Figure 1. Location Map of the Study Area

\section{SOCIO- ECONOMIC INDICATORS}

There are seven mouzas $^{3}$ viz., Majhipara, Noabila, Dariwala, Siddheswarbati, Daibagyapur, Palashi and Nagdaha around Mathura beel. Each mouza have two to three villages. Mainly Majhipara village, there are about 3144 inhabitants as per Census data 2001. The size of the sample of the total interviewed families is 2094 . From this sample, 4901 are male and 5570 are female. It is found that Nagdaha (4502) is the most populated mouza while Dariwala (397) is the least populated mouza. The total size of the sample is 10471, of which 1746 (16.67\%) are children; 8176 (78.08\%) are working population and $549(5.25 \%)$ are aged population. Out of the seven mouzas, the sample shows that Nagdaha has the highest child population (512) and the highest working population (3771). Daibangopur has the lowest child population (60) and the lowest working population (233). The demographic features of area adjoining mouzas of the Mathura beel are depicted in Table 2.

It is found that the percentage of illiterates are $29 \%$ whereas, the $31 \%$ of the sample are literate. Moreover, except the mouza, Nagdaha, male literates are more than females almost at all levels of education. The rate of illiteracy is at the highest percentage in Nagdaha mouza and this mouza is also the highest in literate population compared to other sample mouzas. It is also observed that in the age group 15-59, non-earners (51.44\%) are more than the earners (48.56\%). From the sample, it can be stated that the occupational structure of the villages of the respondents' families is categorized as out of the total force of 5085 in various sector, $743(14.6 \%)$ are cultivators, 841 $(16.56 \%)$ belong to agricultural landless laborers, $794(15.64 \%)$ belong to rural cottage industry, 149 (2.56\%) belong to animal husbandry, $756(14.87 \%)$ belong to businessmen, $313(6.15 \%)$ belong to service holders, $629(12.30 \%)$ belong to fishermen, and remaining $860(16.92 \%)$ belong to the other occupation. The whole scenario is depicted in the following pie diagram Figure 2. In labor participation, it is observed that the percentage of workforce to labor force constituted around $71.77 \%$. Permanent workers are more than temporary and seasonal workers in the total workforce in the all mouzas. The result depicts that the work force in the case of employed is maximum than unemployed.

\footnotetext{
${ }^{3}$ Mouzas: Mouzas (mouza) are constituents of a block according to land reform of West Bengal Government, India.
} 
Table 1. Annual Average data (January-December, 2007 to 2009) on water quality parameter of Mathura Beel

\begin{tabular}{llllllllll}
\hline $\begin{array}{l}\text { Sampling } \\
\text { Stations }\end{array}$ & $\begin{array}{l}\text { Temp } \\
\left({ }^{0} \mathrm{C}\right)\end{array}$ & $\begin{array}{l}\mathrm{DO} \\
\left(\mathrm{mg} \mathrm{L}^{-1}\right)\end{array}$ & $\mathbf{p H}$ & $\begin{array}{l}\mathrm{BOD} \\
\left(\mathrm{mg} \mathrm{L}^{-1}\right)\end{array}$ & $\begin{array}{l}\mathrm{SO}_{4}^{-2} \\
\left(\mathrm{mg} \mathrm{L}^{-1}\right)\end{array}$ & $\begin{array}{l}\text { Phos- } \\
\text { phorous as } \\
\mathrm{PO}_{4}^{-3} \\
\left(\mathrm{mg} \mathrm{L}^{-1}\right)\end{array}$ & $\begin{array}{l}\text { TC } \\
(100 \\
\mathrm{MPN} \text { per } \\
\mathrm{mL})\end{array}$ & $\begin{array}{l}\text { FC } \\
(100 \mathrm{MPN} \\
\text { per mL })\end{array}$ & $\begin{array}{l}\text { Chloro- } \\
\text { phyll-a } \\
\left(\mu \mathrm{L}^{-1}\right)\end{array}$ \\
\hline $\begin{array}{l}\text { Middle of the } \\
\text { lake }\end{array}$ & 19.7 & 4.75 & 7.0 & 2.25 & 32.86 & 0.359 & 350 & 12 & 98 \\
\hline $\begin{array}{l}\text { In front of } \\
\text { algae } \\
\text { formation }\end{array}$ & 19.6 & 5.18 & 7.5 & 2.4 & 43.56 & 0.0122 & 1000 & 10 & 102 \\
\hline $\begin{array}{l}\text { In front of } \\
\text { bathingghat }\end{array}$ & 20.2 & 5.68 & 7.5 & 3.1 & 37.44 & 0.0057 & 900 & 9 & 165 \\
\hline Average & 19.82 & 5.20 & 7.3 & 2.58 & 37.95 & 0.1256 & 750 & 10 & 122 \\
\hline
\end{tabular}

Table 2. Demographic profile in the adjacent mouza of the Mathura beel (data from January-December, 2008 to 2009 and census of India, 2001)

\begin{tabular}{lcccccccc}
\hline $\begin{array}{l}\text { Name of the } \\
\text { mouzas }\end{array}$ & \multicolumn{2}{c}{$\begin{array}{c}\mathbf{0 - 1 4} \text { child } \\
\text { population }\end{array}$} & \multicolumn{2}{c}{$\begin{array}{c}\text { 15-59 working } \\
\text { population }\end{array}$} & \multicolumn{2}{c}{$\begin{array}{c}\text { Above 60 age } \\
\text { population }\end{array}$} & \multicolumn{2}{c}{$\begin{array}{c}\text { The total } \\
\text { sample }\end{array}$} \\
\cline { 2 - 11 } & Male & Female & Male & Female & Male & Female & Male & Female \\
\hline Majhipara & 183 & 165 & 521 & 573 & 37 & 60 & 741 & 798 \\
\hline Noabila & 71 & 47 & 333 & 110 & 75 & 10 & 479 & 167 \\
\hline Dariwala & 66 & 62 & 112 & 126 & 10 & 21 & 188 & 209 \\
\hline Shidherswarbati & 52 & 49 & 323 & 261 & 21 & 13 & 396 & 323 \\
\hline Daibangopur & 33 & 27 & 137 & 96 & 14 & 11 & 184 & 134 \\
\hline Palashi & 252 & 227 & 948 & 865 & 20 & 38 & 1220 & 1130 \\
\hline Nagdaha & 203 & 309 & 1401 & 2370 & 89 & 130 & 1693 & 2809 \\
\hline
\end{tabular}

\section{Per Capita Income of the Household}

The annual per capita income of the study area is Rs.15012.94. The total sample size of the earner stakeholders of the Majhipara mouza is 68 and their annual income is Rs.903306.6 and hence the per capita annual income is Rs.1433.82; Noabila mouza has a sample size of earner stakeholders of 164, with an annual income of Rs.233782 and, so, its per income is Rs.1425.50; the stakeholders of Dariwala mouza have annual income Rs.186658.9 and the sizes of the sample of the earner people of this mouza are 133 and, hence the per capita income is Rs.1403.45.

The annual income of Shidherswarbati is Rs.481923.5, with the size of sample of employed stakeholders are 179 and hence the per capita income of this mouza is Rs.2692.31. The people in Daibangopur have annual income of Rs.163200 and the size of the sample of the earner stakeholders is 68 . So, the per capita of Daibangopur income is Rs.2400. The Palashi has an annual income of Rs.2640300 with sample of earner people 624 and hence it has per capita income of Rs.4231.25. Nagdaha has an annual income of Rs.634269.4 with a sample of employed people is 1486 and hence it has per capita income of Rs.426.83. Of all the mouzas, in the study area, Palashi stands first in terms of per capita income, whereas the per capita income is the lowest in Dariwala mouza. The total picture of the per capita income of all mouzas is penciled in the Figure 3. 


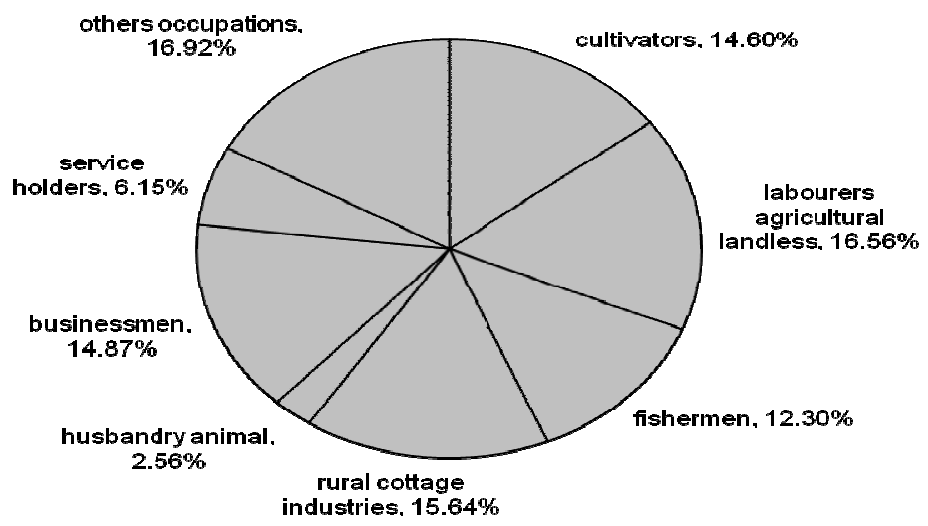

Figure 2. Occupational structure of the sample population of Mathura beel

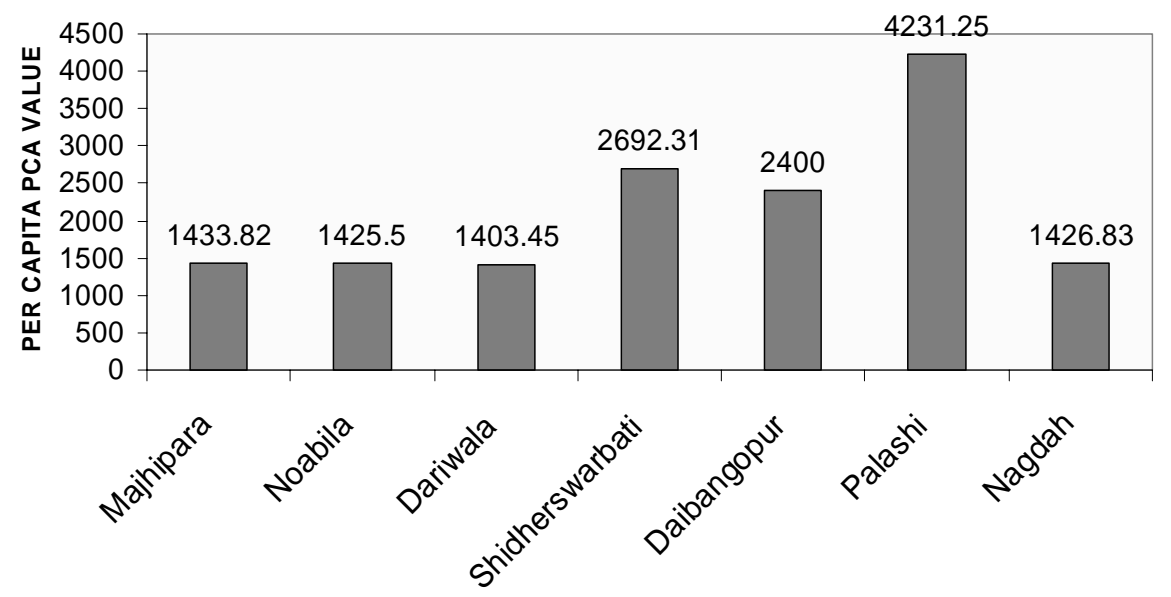

Figure 3. Per capita annual (PCA) income of the sample, in the adjoining mouza of Mathura beel

\section{Pattern of Job Willingness}

Job willingness of the workforce (respondents and their members) is inferred that $3179(26.05 \%)$ are interested to rear poultry, $1562(15.49 \%)$ are willing to rear duckery, $3415(30.28 \%)$ are interested in goatery, $82(2.11 \%)$ are interested in vermicompose, $246(6.33 \%)$ are willing to carry out water nut cultivation activities, $54(1.39 \%)$ are interested to continue their shola cultivation work, $445(11.45 \%)$ are busy in mat stick cultivation, $670(17.24 \%)$ are willing to do medicinal plant cultivation, and the rest $800(20.58 \%)$ prefer to go for any work on fishery cultivation. It is seen that 2350 workforce people (respondent and their members) in Palashi are much interested in carrying out all activities, followed by Noabila with 646 members, 318 members each from Daibangopur, 4502 members from Nagdaha and 397 members from Dariwala, 719 members from Shideswarbati and 1539 member from Majhipara.

\section{Perception of Function and Threats to Wetland}

The wetland use and threats to wetland have been made on the basis of household survey. Based on ranking, the seven important types of wetland use have been shown in Figure 4 . It is found that the people responses are maximum in fishing whereas scenic beauty, washing, domestics animal bathing, shell fish cultivation, other aquatic flora cultivation and using for human bathing purpose followed in rank 2, rank 3, rank 4, rank 5 , rank 6 and rank 7 respectively for wetland use. On the other side, in the Figure 5 , it is depicted that the wetlands are subjected to maximum threat for sedimentation rather than eutrophication and sewage whose rank numbers are 2 and 3 respectively 
and solid waste dumping, over fishing, detergent use, and mixing of agricultural wash out followed in rank 4, rank 5, rank 6 and rank 7 .

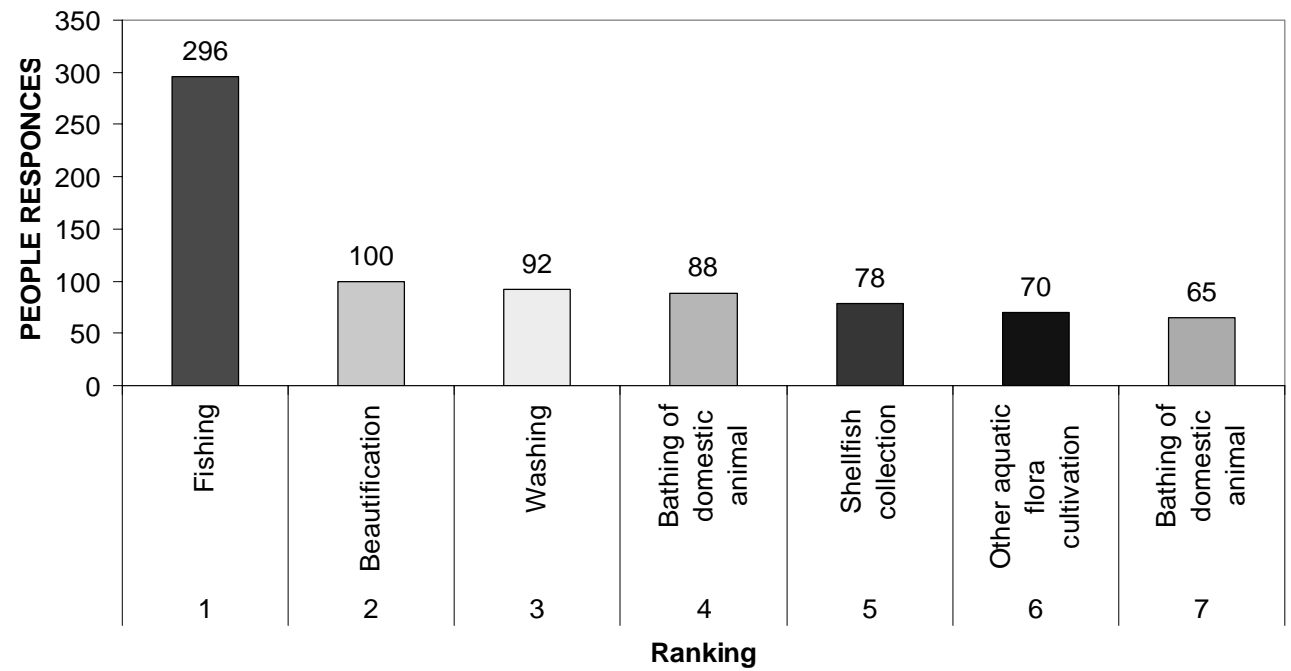

Figure 4. Ranking of Wetland Uses awarded by Sample Population

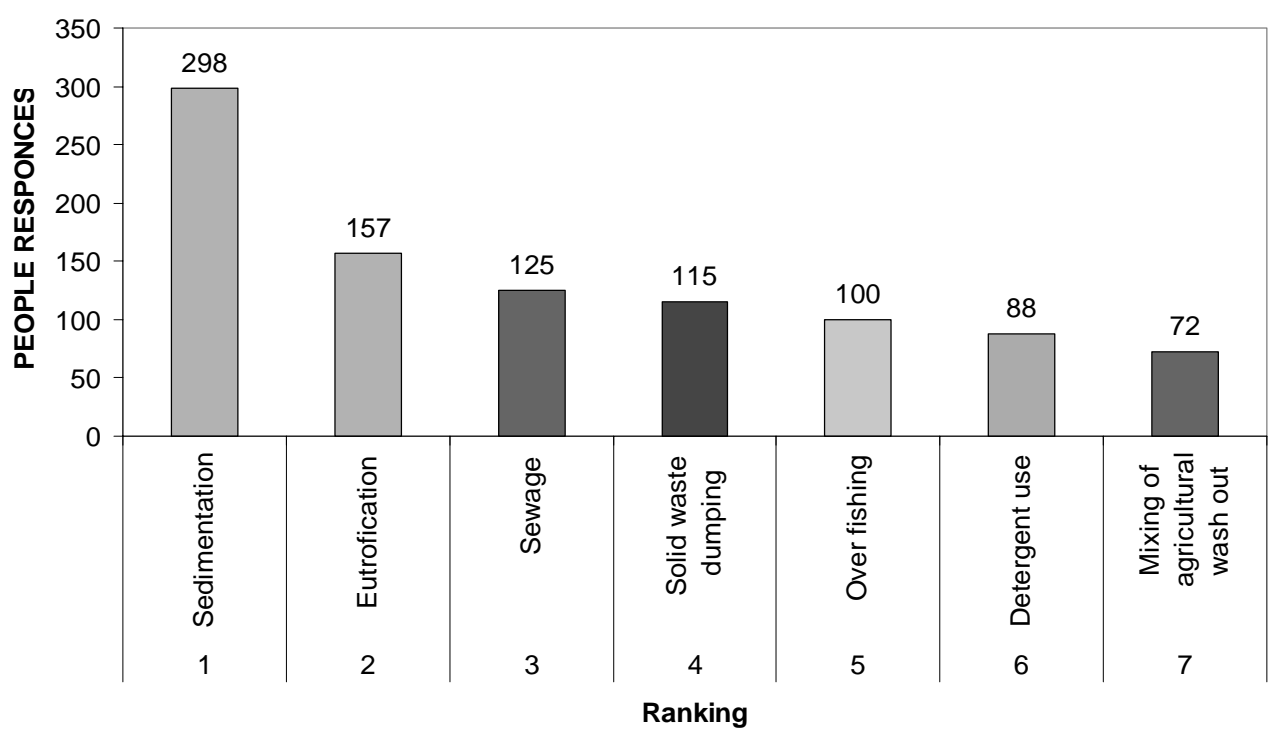

Figure 5. Ranking of Wetland Threat awarded by Sample Population

\section{CONCLUSION}

Wetlands are among the most important and yet most threatened eco-systems in India. They are a precious part of our cultural and natural heritage, providing and extremely important resource for many human interest and activities, as well as habitats that support a rich diversity of animal and plant life. As the present study, Mathura beel is an important wetland in this floodplain area, it is concluded that fishing is its major function throughout the year in comparison to the agro-irrigation, where huge water withdrawal is necessary. But the main problem is that the fish production has reduced by almost 60\% during the last fourteen years (period from 1992 to 2007), owing not only to the high siltation rate, in and around the wetland, but also as a result of increased pollution loads from anthropogenic activities.

Participation of stakeholders can solve many problems of wetlands. Moreover with proper knowledge, participations of stakeholders can conserve the wetland and its eco-system. Hence, for successful watershed management in any situation, a participatory and integrated approach is essential. But simultaneously, it is also noted that good coordination and communication skills at all levels are essential in order to achieve watershed planning and management, which would otherwise fail. 
The hydrological interventions are expected to help considerably the enhancement of fishery resources, water quality, checking the weed infestation, maintaining proper dissolved oxygen levels, auto recruitment of fish, prawn and crab juveniles, conservation of biodiversity and in overall increase in productivity. This will help not only enhancing the per capita income but also poverty alleviation of the dependent community in and around the Mathura beel.

From the detailed qualitative and quantitative study, the demographic picture of all the mouzas of Mathura beel is revealed. With help of a large sample, it can be concluded that nowadays people are more interested to get academic education because the number of literate people is higher than the number of illiterate people in the mouzas. In this connection, it can also be concluded that apart of few places, male literates are more than the females, at almost all levels of education. In this qualitative and quantitative study, the occupational structure, the ratio of earners and non-earners, and pattern of job willingness are also reviewed. In case of occupational structure, it can be remarked that the people are more interested in agriculture, fishing, cottage industry, and animal husbandry than other occupations, which means that people in these mouzas are interested to depend on this lake by their occupation and this dependency can also be viewed in case of job willingness pattern, where the main interest of the stakeholders lies in duckery, goatery and poultry. But the study indicates that the ratio between earners to non-earners is less than 1 , which means the number of non-earners is higher than earners. As per objectives, a perception study was also carried out on wetland uses and wetland threats.

The study exposed that in this region, the stakeholders prefer fishing than scenic beauty, washing, domestics animal bathing, shell fish cultivation, other aquatic flora cultivation and water using for human bathing purposes. Moreover, wetlands are subjected to maximum threat from sedimentation rather than eutrophication, sewage, solid waste dumping, over fishing, detergent use, and mixing of agricultural wash. Thus, in an attempt to find new solutions to the various problems in the watershed management resulting from top-down approaches to resource conservation and sustainability, community-based co-management recognizes that local communities should have direct control over the management, utilization and benefits of local resources (in this context land, water and fishery resources) in order to value and use them in a sustainable manner.

\section{Management options}

A series of management options are suggested as necessary for the sustainable management of this wetland.

Ban on use of plastics, prevention of non-point source pollution, and implementation of integrated Solid Waste Management (SWM) as per the guidelines of the national SWM committee are needed.

Reduction of siltation through appropriate land use and land cover approach is essential to conserve the lake, as the main livelihood in the region of Mathura beel depends on wetlands, through various occupations and activities.

Earthen dyke should be protected from soil erosion by wooden pilling in two/three layers towards hill along with generation of grass cover through Vetiver Grass Technology (VGT) in the watershed areas to check erosion.

Biological studies and regular stock assessment of important flora and fauna are necessary for the environment of Mathura beel to protect the biodiversity, since Mathura beel is enriched with high biodiversity level.

Water quality analysis shows that the significance effects of the stations and the depth of beel on different water quality parameters. Therefore, the regular monitoring of water quality and developing a database for risk evaluation is essential for the water of Mathura beel. In this case, it should be noted that advanced pisciculture techniques can increase the productivity of the water resource in the Mathura beel. Thus, local government should look upon on the seriousness of this technique for betterment of the water of the lake.

A coordinate planning for the water quality of the wetland is utmost necessary to assess the agricultural and other biotic pressure on the wetland and to evolve on an integrated management strategy for the development of economy and ecosystem of the wetland and watershed.

It is proposed to convert organic waste generating in Mathura beel area to organic compost through Vermi-culturing. Accordingly a land has been earmarked in and around the lake for this purpose. The 
organic waste generated in the eating-houses and water hyacinth (day- to- day lifting for maintenance of the wetland) etc would be converted into compost.

Culture based fisheries with the advent of culture based capture fisheries, culture and capture system are merged into one integrated whole. The present strategy for optimum exploitation of flood plain wetland fisheries revolves around the concept of keeping the deeper central portions as exclusive zones fop capture fisheries and renovation of margins/pockets for culture fisheries. Desilting of connecting channels and construction of perimeter dykes are prerequisite for such exercise. The most of the wetlands have pockets retaining water throughout or part of the year. By way of micro-dams /sluice, this pocket can be converted into dams. Intensive aqua culture practices are suggested for such water bodies. It is also stressed to adopt integrated fish farming rather than composite fish culture alone. A multi-commodity farming system is more advantageous to the farmer, if the commodity mix fits well into the available resources and needs, than the monocropping system. The duck husbandry with fish culture will be gaining popularity due to high returns.

The sustainable development of commercial fisheries in the Mathura beel can involve a recurring expenditure on the collection of spawn and its transport for stocking. Auto stoking of Indian major craps during floods in such wetland, therefore, is the only viable alternative for a quick and profile development. For this reason, the de-silting of connecting channels and their effective management is a pre-requisite. The operation of sluice gates, wherever it is installed, is to be oriented in such a way as to facilitate entry of brood fish and juveniles into the lake proper. This would entail suitable legislation to overcome the conflict between agriculture and fisheries.

Finally, the participation of each and every stakeholder is needed more, not only preserve or conserve the Mathura beel, but also emerging his or her life style and livelihood and this whole process can be successful through proper training of stakeholders of Mathura beel. In this connection, it could also be stated that the biggest benefit of utilizing the water resource would be the opportunity for employment of large number of people those benefiting the economy of the district.

\section{REFERENCES}

Acreman M.C. and Hollis G.E. (Eds). (1996) Water Management and Wetlands Sub-Saharan Africa, IUCN, Switzerland.

Bakker M. and Matsuno Y. (2001) A framework for valuing ecological services of irrigation water: A case of an irrigation-wetland system in Sri Lanka, Irrigation and Drainage Systems, 15, 99-115.

Biswas M. (2008) Participatory management of ecosystem services: A study of wetland in West Bengal, Ph.D thesis, School of Water Resources Engineering, Jadavpur University, Kolkata, India.

Biswas M., Bandyopadhyay S., Roy P.K. and Mazumdar A. (2005) A holistic approach of participatory management of wetland: Bhomra Beel - A Case Study, Journal of the Institution of Public Health Engineers, India, 4, 37-41.

Biswas M., Roy P.K. and Mazumdar A. (2007) A comparative study of users' perception of wetland regions, Journal of Environmental Protection, 27(3), 209-215.

Boyacioglu H., Boyacioglu H. and Gunduz O. (2005) Application of factor analysis in assessment of surface water quality in Buyuk Menderes River Basin, European Water, E.W. Publications, 9/10, 4349.

Census of India (2001) Government of India, Office of the Registrar General \& Census Commissioner, India.

Donah K.K. (1995) Wetland conservation: Institutional Constraints and Community Awareness, Case studies from developing countries, UNEP EIA Training Resource Manual, Uganda, 111-116.

Dixon A.B. (2008) The resilience and sustainability of local wetland management institutions in lllubabor and Western Wellega, Ethiopia. Singapore, Journal of Tropical Geography, 29(3), 341-356.

Gopal B. and Sah M. (1995) Inventory and Classification of Wetlands in India, J. Plant Ecology, 118(1- 2), 39-48.

IUCN, CNRS-Bangladesh. (2006) Coastal and Wetland Biodiversity Management Project: Hakaluki Haor Component. Natural Resource Economic Evaluation of Hakaluki Haor (Contract No: ADM/250/52/2005). Ministry of Environment and Forests, Government of Bangladesh.

Jansson M., Anderson R., Berggren H. and Leonardson L. (1994) Wetlands and Lakes as Nitrogen traps, Ambio, 23, 320-325. 
Kangalawe R.Y.M. and Liwenga E.T. (2005) Livelihood in the wetlands of Kilombero Valley in Tanzania: Opportunities and challenges to integrated water resources management. Elsevier, J. Physics and Chemistry of the Earth, 30, 968-975.

Kusler, J., Brinson, M., Niering, W., Patterson, J., Burkett V. and Willard, D. (1999) Wetlands and climate change: scientific knowledge and management options, Institute for Wetland Science and Public Policy, Association of Wetland Managers, Berne, NY, USA.

Makombe G. and Sampath R.K. (2003) A Comparative Analysis of the Influence of Socioeconomic Variables on the Financial Performance of Smallholder Irrigation Systems in Zimbabwe. International Water Resources Association, 28, 416-421.

Mitsh W.J. and Gossolink J.G. (1993) Wetlands second edition. Van Nostrand Reinhold, New York.

Mukherjee S. (2008) Economic Valuation of a Wetland in West Bengal, India. International Water Management Institute (IWMI)-TATA Water Policy Research Program Seventh Annual Partners' Meet 1, MPRA, 254-266.

Mwakubo S.M., Obare G.A., Birungi P., Rono P.K. and Karamagi I. (2004) Status and challenges of wetlands management towards livelihood improvement: The case of lake Victoria wetlands, http://users.ictp.it/ eee/workshops/smr1686/Mwakubo.doc.

Singh S.P., Gopal B. and Kathuria V. (2001) Integrated Management of water resources of Lake Nainital and its Watershed: An Environment Economic Approach, EERC Indira Gandhi Institute of Development Research, Mumbai, SpringerLink.

Thompson J.R. (1996) Africa's floodplains: a hydrological overview. In: Acreman, M.C., Hollis, G.E. (Eds.), Water Management and wetlands in Sub-Saharan Africa. IUCN. Gland, 5-20.

Tiega A. (2002) Priorities for wetland biodiversity conservation in Africa. Ramsar Convention Bureau, Rue Mauverney 281196 Gland, Switzerland, 112-120.

Turner R.K. (2000) Valuation of Wetlands in a Landscape and Institutional Perspective. J. Ecological Economics, 35, 1-6.

Zeng X. and Rasmussen T.C. (2005) Multivariate Statistical Characterization of Water Quality in Lake Lanier, Georgia, USA. Journal of Environmental quality, 34, 1980-1991. 